\title{
Antimicrobial activities of edible plant extracts against oral bacteria
}

\author{
Jihye Lee ${ }^{1} \cdot$ Yeona Kim ${ }^{1} \cdot$ Dong Chung Kim² ${ }^{2}$ Hee Jeong Chae ${ }^{1}$

\section{식용 식물추출물의 구강 세균에 대한 항균 활성} \\ 이지혜 ${ }^{1} \cdot$ 김연아 $^{1} \cdot$ 김동청 $^{2} \cdot$ 채희정 $^{1}$
}

Received: 14 January 2020 / Accepted: 24 February 2020 / Published Online: 31 March 2020

(C) The Korean Society for Applied Biological Chemistry 2020

\begin{abstract}
Thirty-five edible plants were tested against oral bacteria (Streptococcus mutans, Lactobacillus casei, Staphylococcus epidermidis, Klebsiella pneumonia). The edible plants were extracted using $70 \%$ ethanol as a solvent. Among the thirty-five edible plants, hibiscus (Hibiscus sabdariffa) extract was selected as an effective antibacterial source because it showed the lowest minimum inhibitory concentration. The antimicrobial substances of hibiscus extract were very stable at acidic condition and at wide range of temperature $4-75^{\circ} \mathrm{C}$. The total polyphenol and flavonoid contents of hibiscus extract were 130.5 and $25.7 \mathrm{mg} / \mathrm{g}$, respectively. Also hibiscus extract showed a high degree of antioxidant activity.
\end{abstract}

Keywords Antimicrobial activity $\cdot$ Edible plant extract $\cdot$ Hibiscus sabdariffa $\cdot$ Minimum inhibitory concentration $\cdot$ Oral bacteria

\section{서 론}

미생물과 쉽게 접촉하는 신체 부위인 구강은 적절한 온도, 습 도 및 음식물 잔사등으로 인해 미생물의 생육에 좋은 환경을

Hee Jeong Chae $(\triangle)$

E-mail:hjchae@hoseo.edu

${ }^{1}$ Department of Food and Pharmaceutical Engineering, Hoseo University, Asan 31499, Republic of Korea

${ }^{2}$ Department of Chemical Engineering, Chungwoon University, Incheon 22100, Republic of Korea

This is an Open Access article distributed under the terms of the Creative Commons Attribution Non-Commercial License (http://creativecommons. org/licenses/by-nc/3.0/) which permits unrestricted non-commercial use, distribution, and reproduction in any medium, provided the original work is properly cited.
제공해주며, 구강 내에서는 700 여 종의 다양한 세균이 존재하는 것으로 보고되어 있다[1]. 그 중에는 충치의 원인균으로 널리 알 려진 Streptococcus mutans[2]와 Lactobacillus casei[3], 구강 인 두와 피부에 상주하며 화농성 염증을 유발하는 Staphylococcus epidermidis[4], 휘발성 황화합물을 생성하여 구취를 유발하는 Klebsiella pneumonia 등이 대표적인 구강세균으로 알려져 있다 [5]. 구강 질환은 충치(dental caries, 치아우식증), 구내염, 치주 염 등 입안에서 생기는 병을 일컫는데, 특히 충치는 구강 질환 중 가장 문제가 되는 감염병으로 치아표면의 파괴를 동반한다 [6]. 대표적인 충치 유발균인 Streptococcus mutans는 치아 표면 에서 glucosyltransferase의 촉매 작용으로 음식물의 sucrose를 분해하여 acetic acid 및 citric acid 등의 산을 생성하고, 이는 치아 에나멜층의 hydroxyapatite를 부식하여 치아 표면을 손실 시킨다[2].

충치 유발균을 포함하는 구강 세균의 억제에 penicillin 및 erythromycin과 같은 항생제가 효과가 있는 것으로 알려져 있으 나, 항생제에 대한 내성 문제로 실제로는 잘 사용되지 않는다 [7]. 또한 항생제의 과도한 사용은 구강 미생물 뿐만 아니라 우 리 몸에 유익한 장관 미생물 균총에도 악영향을 줄 수 있다[8]. 이외에도 구강 세균을 억제하기 위해 불소 화합물이 함유되어 있는 구강청결제와 치약 등의 의약외품이 사용되고 있는데 일 부 성분에 대한 안전성 이슈와 논란이 보고되고 있다[9].

따라서 인간에게 독성이 없거나 적으면서 안정성이 높은 구 강용 항미생물 소재의 개발이 요구되어 충치 유발균의 증식을 억제하는 방법[10], 충치균이 분비하는 glucan 합성 효소인 glucosyltransferase의 활성을 저해하는 방법[11], 충치 유발균이 이용하기 쉬운 sucrose를 대체하는 감미료를 사용하는 방법[12] 등이 알려져 있다. 또한 식물추출물을 대상으로 구강 관련 천 연 소재를 탐색하는 연구가 꾸준히 진행되고 있으며[13], 그 대 표적인 예로 감국[14], 황련[15] 및 솔잎[16] 추출물은 충치균의 생장을 억제한다고 알려졌고, 오미자[17]와 연[18] 추출물은 구 강 세균의 성장 억제와 구취 제거에 효과적임이 보고되었다. 
본 연구에서는 35 종의 식용 식물을 대상으로 구강 세균에 대 한 항균 활성을 측정하여 히비스커스(Hibiscus sabdariffa) 추출 물이 가장 효과적인 것을 확인하였다. 히비스커스는 열대아시아 및 서아프리카가 원산지인 무궁화속 아욱과의 식물이며 보통 물 로 추출하여 음용하는데[19], 그 추출물에는 사과산, 구연산 등 이 들어있어 신맛을 가지며 안토시아닌계 색소로 인해 밝은 적 색을 나타낸다[20]. 또한 히비스커스에는 비타민 C가 풍부하고 칼륨, 칼슘, 철, 마그네슘 등의 무기질이 많이 함유되어 있으며, 기능성 성분으로는 플라보노이드계 물질인 gossypectin이 알려 져 있다. 히비스커스는 눈의 피로 회복, 소화기능 강화, 강장, 이뇨, 출혈 방지 및 비뇨기계 염증 완화 등의 효능이 있는 것 으로 알려져 있어[21] 생리활성 소재로의 활용 가능성이 높은 식물이다. Kang 등의 연구[22]에서는 피부 관련 미생물에서 히 비스커스 에탄올 추출물의 항균활성을 확인한 바 있으며, 본 연 구에서는 구강에 관련된 미생물에서의 항균활성을 확인하고자 한다.

구강 미생물(Streptococcus mutans, Lactobacillus casei, Staphylococcus epidermidis 및 Klebsiella pneumonia)에 대하여 항균 효과를 갖는 식물추출물을 탐색하여 가장 활성이 우수한 히비스커스를 구강용 항균 천연소재로 선정하였고, 또한 히비스 커스 추출물의 항균 활성 및 항산화 활성을 평가하여 구강 위 생용 생리활성 소재로의 개발 가능성을 검토하였다.

\section{재료 및 방법}

\section{실험재료}

본 실험의 식용 식물 원료 35 종은 대형마트 또는 한약소재 전 문 쇼핑몰을 통하여 구매하여 사용하였고, 식물 원료의 사용부 위와 원산지는 Table 1과 같다. 건조 상태의 재료는 그대로 추 출에 사용하였고, 생물 상태의 재료는 흐르는 수도수를 이용하 여 세척하고 열풍건조기(Taeyang Electric Co., Goyang, South $\mathrm{Korea}$ )를 이용하여 $40^{\circ} \mathrm{C}$ 에서 $24-48$ 시간 동안 건조 과정을 거 친 후 실험에 사용하였다.

추출 용매인 정제수와 에탄올은 Burdick \& Jackson사 (Muskegon, MI, USA)의 HPLC급 제품을 사용하였고, 기능성 평가에 사용된 folin-ciocalteu, 1,1-diphenyl-2-picrylhydrazyl $(\mathrm{DPPH})$ 시약과 표준물질로 사용된 chlorogenic acid, naringin, ascorbic acid는 Sigma-Aldrich사(St. Louis, MO, USA)의 제품 을, 그 외 시약은 1 급 이상을 사용하였다.

\section{균주 배양}

본 연구에서 사용한 균주는 4종의 구강세균 Streptococcus mutans KCTC 3065, Lactobacillus casei KCTC 3109, Staphylococcus epidermidis KCTC 1917, Klebsiella pneumoniae KCTC 2208과 위생지표균 Escherichia coli KCTC 2441으로, 생물자원센터(Korean Collection for Type Cultures, Jeongeup, South Korea)에서 분양 받아 사용하였다. Streptococcus mutans KCTC 3065는 Brain Heart Infusion 배지에서, Lactobacillus casei KCTC 3109는 Lactobacilli MRS Broth 배지에서 배양하 였다. Staphylococcus epidermidis KCTC 1917와 Klebsiella pneumoniae KCTC 2208와 Escherichia coli KCTC 2441는
Nutrient Broth 배지를 사용하여 배양하였다. 다섯 종의 균 모두 $37^{\circ} \mathrm{C}$ 로 셋팅된 진탕 배양기(VS-8480SFN, VISION Scientific, Daejeon, South Korea)를 사용하여 호기성 조건에서 배양하였으 며, 24 시간 또는 48 시간 동안 배양하여 $1 \times 10^{7} \mathrm{CFU} / \mathrm{mL}$ 의 균을 항균 활성 분석에 사용하였다.

\section{식용 식물추출물의 제조}

건조된 시료 $20 \mathrm{~g}$ 에 $70 \%$ 에탄올을 $100 \mathrm{~mL}$ 씩 가하여 실온에서 24 시간 추출한 후 같은 양의 용매를 다시 가하여 $60{ }^{\circ} \mathrm{C}$ 에서 4 시간 동안 진탕추출하였다. 추출물은 Whatman No. 1 여과지로 여과한 뒤 감압농축기(Eyela, Tokyo Rikakikai Co., Tokyo, Japan)로 농축한 후, 당도계(Master refractometer, Atago, Tokyo, Japan)를 사용하여 5 brix 농도로 제조하였다.

\section{항균 활성 평가}

항균 활성 평가는 Higasi[23]의 방법과 같이 paper disc법을 이 용하였으며, 계대배양을 통해 활성화시킨 균은 멸균 생리식염수 에 현탁하여 $1 \times 10^{7} \mathrm{CFU} / \mathrm{mL}$ 의 농도로 맞춘 후 실험에 사용하 였다. 주입평판법에 따라 petri dish에 균 현탁액 $1 \mathrm{~mL}$ 를 분주 한 후 용해된 고체배지를 주입하여 사용하였다. 제조된 고체배 지 위에 $8 \mathrm{~mm}$ filter paper disc를 놓고 진공농축한 $5 \mathrm{brix}$ 의 시료 $20 \mu \mathrm{L}$ 를 흡수시킨 후 $37^{\circ} \mathrm{C}$ 에서 24 시간 동안 배양하여 관 찰하였다.

최소저해농도(minimum inhibitory concentration, $\mathrm{MIC}$ ) 측정 은 추출물을 $0.45 \mu \mathrm{m}$ filter (Whatman International, England) 를 이용하여 제균한 후 단계희석법(serial dilution method)을 통 해 농도별 시료를 제조하여 사용했다. 96 well plate에 희석된 시료 $50 \mu \mathrm{L}$ 와 $1 \times 10^{5}-10^{6} \mathrm{CFU} / \mathrm{mL}$ 로 희석한 균 현탁액 $50 \mu \mathrm{L}$ 를 혼합한 뒤 균주별 증식용 배지 $150 \mu \mathrm{L}$ 를 넣고 24시간 동안 배양한 후 microplate reader (VERSAmax, Molecular Devices, San Jose, CA, USA)를 사용하여 흡광도를 측정하였고, 균체의 성장이 억제되어 탁도로 나타나지 않는 최소의 농도를 최소저 해농도(MIC)로 정하였다.

\section{항균 활성의 안정성 평가}

산과 알칼리에 대한 항균 활성의 안정성 평가를 위해 농도별 히비스커스 추출물을 $1 \mathrm{~N} \mathrm{NaOH}$ 또는 $1 \mathrm{~N} \mathrm{HCl}$ 수용액을 이용 하여 $\mathrm{pH}$ 를 3, 5, 7 및 9로 조정한 후 $25^{\circ} \mathrm{C}$ 에서 3시간 방치하 였다. 이후 본래의 $\mathrm{pH}$ 로 조절한 후 균 배양액을 첨가하여 최소 저해농도를 측정함으로써 $\mathrm{pH}$ 에 대한 안정성을 평가하였다. 온 도에 대한 안정성은 농도별 히비스커스 추출물을 $4,25,50$ 및 $75^{\circ} \mathrm{C}$ 에서 30 분간 방치한 후 균 배양액을 첨가하여 확인된 최 소저해농도를 측정하여 확인하였다.

\section{항산화 활성 평가}

총 폴리페놀 함량 측정은 Folin-Denis assay법으로 Lee 등[24] 의 방법을 변형하여 분석하였다. 시료 희석액 $100 \mu \mathrm{L}$ 에 folinciocalteu 시약 $50 \mu \mathrm{L}$ 를 첨가하여 혼합한 뒤 4 분 동안 반응시키 고, $20 \% \quad \mathrm{NO}_{2} \mathrm{CO}_{3}$ 를 $1.5 \mathrm{~mL}$ 가하여 2분간 방치한 후 $760 \mathrm{~nm}$ 의 파장에서 흡광도를 측정하였다. Chlorogenic acid를 총 폴리 페놀 함량 분석의 표준물질로 선정하여 표준곡선으로부터 총 폴 리페놀의 함량을 계산하였다. 총 플라보노이드 함량은 $\mathrm{Kim}$ 등 
Table 1 List of edible plants used for the screening of antimicrobial plant extracts against oral microorganisms

\begin{tabular}{|c|c|c|c|}
\hline Scientific name & Common name & Part used & Origin \\
\hline Aspalathus linearis & Rooibos & Flower & Korea \\
\hline Houttuynia corbata & Ouseongcho & Leaf & Korea \\
\hline Chaenomelis fructus & Mogwa & Fruit & Korea \\
\hline Angelica gigas Nakai & Danggwi & Root & Korea \\
\hline Eucalyptus dives & Peppermint & Leaf & Korea \\
\hline Menthae herba & Bakha & Leaf & Korea \\
\hline Hibiscus sabdariffa & Hibiscus & Flower & Korea \\
\hline Perilla frutescens & Jasoyeop & Leaf & Korea \\
\hline Matricaria chamomile & Chamomile & Flower & Korea \\
\hline Sophora flavescens Ait. & Gosam & Root & Korea \\
\hline Glycyrrhiza uralensis & Gamcho & Root & Korea \\
\hline Lycium Chinense & Gugija & Fruit & Korea \\
\hline Cinnaamomum cassia & Gyepi & Bark & Korea \\
\hline Kalopanax picyus Nakai & Umnamu & Bark & Korea \\
\hline Phellodendri cortex & Hwangbaek & Bark & China \\
\hline Schizandra chinensis & Omija & Fruit & Korea \\
\hline Curcuma longa L. & Ulgeum & Root & Korea \\
\hline Commiphora molmol Engl. & Molyak & Resin & China \\
\hline Cymbopogon citratus & Lemongrass & Leaf & Korea \\
\hline Rose canina & Rosehip & Flower & Korea \\
\hline Salvia miltiorrhiza & Dansam & Bark & China \\
\hline Lavandula angustifolia & Lavender & Flower & Korea \\
\hline Pueraria thunbergiana & Chik & Root & Korea \\
\hline Calendula officinalis L. & Marigold & Flower & USA \\
\hline Hovenia dulcis & Heotgae-namu & Bark/Fruit & Korea \\
\hline Vaccinium corymbosum & Blueberry & Fruit & Korea \\
\hline Citrus paradisi & Jamong & Fruit & Korea \\
\hline Punica granatum & Seokryu & Fruit & Korea \\
\hline Allium monanthum & Dalrae & Whole & Korea \\
\hline Platycodon grandiflorum & Yakdoraji & Root & Korea \\
\hline Citrus limon & Lemon & Fruit & Korea \\
\hline Capsella bursa-pastoris & Naengi & Whole & Korea \\
\hline Aronia melanocarpa & Aronia & Fruit & Korea \\
\hline Daucus carota L. & Danggeun & Root & Korea \\
\hline
\end{tabular}

[25]의 방법을 변형하여 측정하였다. 시료 희석액 $0.5 \mathrm{~mL}$ 와 diethylene glycol $5 \mathrm{~mL}$ 를 혼합한 후, $1 \mathrm{~N} \mathrm{NaOH}$ 를 $1 \mathrm{~mL}$ 씩 가 하여 $37^{\circ} \mathrm{C}$ 에서 1 시간 동안 반응시킨 후 $420 \mathrm{~nm}$ 의 파장에서 흡 광도를 측정하였다. 총 플라보노이드 함량 계산용 표준물질은 naringin을 사용하였다.

$\mathrm{DPPH}$ 유리라디칼 소거능은 Heo 등[26]의 방법을 변형하여 분석하였다. 메탄올에 $0.6 \mathrm{mM}$ 의 농도로 희석한 $\mathrm{DPPH}$ 시약 $160 \mu \mathrm{L}$ 와 희석한 시료 $40 \mu \mathrm{L}$ 를 혼합하여 암소에서 30 분간 방 치한 후 $515 \mathrm{~nm}$ 의 파장에서 흡광도를 측정하였다. 환원력은 Hazra 등[27]의 방법을 변형하여 측정하였다. 시료 희석액 $1 \mathrm{~mL}$ 와 $10 \mathrm{mM}$ sodium phosphate 완충용액( $\mathrm{pH}$ 6.6) $1 \mathrm{~mL}$ 를 혼합 한 후 $10 \%$ potassium ferricyanide $1 \mathrm{~mL}$ 를 첨가하여 $50{ }^{\circ} \mathrm{C}$ 에 서 20 분 동안 반응시켰다. 반응액에 $10 \%$ trichloracetic acid를
$1 \mathrm{~mL}$ 주입하고 원심분리 $(10,000 \times \mathrm{g}, 10$ 분)를 하였다. 원심분리 상등액과 $0.1 \%$ ferric chloride를 각각 $100 \mu \mathrm{L}$ 씩 혼합하여 700 $\mathrm{nm}$ 에서 흡광도를 측정하였다.

\section{결과 및 고찰}

\section{Paper disc assay에 의한 식용 식물추출물의 항균 활성}

식용 식물 35 종의 생리 활성 부위를 $70 \%$ 에탄올로 추출하여 구강 세균에 대한 항균 효과를 확인하였다. Table 2는 여러 식 용 식물추출물의 paper disc assay 결과를 나타낸 것으로, 당귀, 박하, 자소엽, 캐모마일, 고삼, 울금, 레몬그라스, 라벤더, 칡, 매 리골드, 헛개나무, 달래, 약도라지, 냉이 및 아로니아 추출물은 
Table 2 Antimicrobial activities of various edible plant extracts against oral bacteria

\begin{tabular}{|c|c|c|c|c|c|c|}
\hline \multicolumn{2}{|c|}{ Experimental sample } & \multicolumn{5}{|c|}{ Zone of inhibition (mm) } \\
\hline \multirow{2}{*}{ Scientific name } & \multirow{2}{*}{ Common name } & \multicolumn{3}{|c|}{ Gram (+) } & \multicolumn{2}{|c|}{ Gram (-) } \\
\hline & & S. mutans & L. casei & S. epidermidis & K. pneumoniae & E. coli \\
\hline Aspalathus linearis & Rooibos & 9 & - & 12 & - & - \\
\hline Houttuynia corbata & Ouseongcho & - & - & 9 & 10 & - \\
\hline Chaenomelis fructus & Mogwa & 9 & - & 17 & 13 & - \\
\hline Angelica gigas Nakai & Danggwi & - & - & - & - & - \\
\hline Eucalyptus dives & Peppermint & 9 & - & 9 & - & - \\
\hline Menthae herba & Bakha & - & - & - & - & - \\
\hline Hibiscus sabdariffa & Hibiscus & 15 & - & 23 & 17 & 13 \\
\hline Perilla frutescens & Jasoyeop & - & - & - & - & - \\
\hline Matricaria chamomile & Chamomile & - & - & - & - & - \\
\hline Sophora flavescens Ait. & Gosam & - & - & - & - & - \\
\hline Glycyrrhiza uralensis & Gamcho & 9 & - & 12 & 10 & - \\
\hline Lycium Chinense & Gugija & - & - & - & 9 & - \\
\hline Cinnaamomum cassia & Gyepi & - & - & 13 & 12 & - \\
\hline Kalopanax picyus Nakai & Umnamu & - & - & 9 & - & - \\
\hline Phellodendri cortex & Hwangbaek & 11 & 12 & - & - & - \\
\hline Schizandra chinensis & Omija & 9 & - & 25 & 17 & 14 \\
\hline Curcuma longa $\mathrm{L}$. & Ulgeum & - & - & - & - & - \\
\hline Commiphora molmol Engl. & Molyak & 9 & - & 15 & 9 & - \\
\hline Cymbopogon citratus & Lemongrass & - & - & - & - & - \\
\hline Rose canina & Rosehip & - & - & 12 & 9 & - \\
\hline Salvia miltiorrhiza & Dansam & - & 10 & 11 & 11 & - \\
\hline Lavandula angustifolia & Lavender & - & - & - & - & - \\
\hline Pueraria thunbergiana & Chik & - & - & - & - & - \\
\hline Calendula officinalis $\mathrm{L}$. & Marigold & - & - & - & - & - \\
\hline Hovenia dulcis & Heotgae-namu & - & - & - & - & - \\
\hline Vaccinium corymbosum & Blueberry & - & - & 12 & - & - \\
\hline Citrus paradisi & Jamong & - & - & 14 & 10 & - \\
\hline Punica granatum & Seokryu & - & - & 12 & - & - \\
\hline Allium monanthum & Dalrae & - & - & - & - & - \\
\hline Platycodon grandiflorum & Yakdoraji & - & - & - & - & - \\
\hline Citrus limon & Lemon & 9 & - & 24 & 17 & 15 \\
\hline Capsella bursa-pastoris & Naengi & - & - & - & - & - \\
\hline Aronia melanocarpa & Aronia & - & - & - & - & - \\
\hline Daucus carota L. & Danggeun & - & - & - & 10 & \\
\hline
\end{tabular}

구강 세균인 S. mutans, L. casei, S. epidermidis, K. pneumoniae 와 보건지표군인 E. coli에 대한 항균 효과가 전혀 없었다.

엄나무, 블루베리 및 석류 추출물은 S. epidermidis에 대해, 구기자 및 당근 추출물은 K. pneumonia에 대해 낮은 항균 활 성을 보였다. 루이보스와 페퍼민트 추출물은 $S$. mutans와 $S$. epidermidis에 대해, 어성초, 계피, 로즈힙 및 자몽 추출물은 $S$. epidermidis와 K. pneumonia에 대해, 황백 추출물은 S. mutans 와 L. casei의 두 종류의 균에 대한 항균 활성을 나타냈다. 모 과, 감초 및 몰약 추출물은 그람양성균인 S. mutans와 $S$. epidermidis, 그람음성균인 K. pneumonia에 대해, 단삼 추출물 은 그람양성균인 L. casei와 S. epidermidis, 그람음성균인 $K$. pneumonia에 대해 항균 활성을 나타내었다. 특히 히비스커스, 오미자 및 레몬 추출물은 그람양성균인 S. mutans와 $S$. epidermidis, 그람음성균인 K. pneumoniae와 E. coli에서 clear zone이 관찰되어 넓은 항균 스펙트럼과 높은 항균 활성을 보였 다. 오미자의 경우 S. epidermidis에 대하여 $25 \mathrm{~mm}$ 로 가장 큰 저해환을 나타냈다. Jeong 등[28]의 결과에 비하여 높은 항균 활성을 보였는데, 이는 추출 용매의 차이에 기인한 것으로 물 보다 $70 \%$ ethanol이 구강 세균에 대한 비극성 항균 물질을 더 많이 추출할 수 있기 때문인 것으로 판단된다.

본 연구에서 스크리닝 대상으로 선정한 식물 유래 추출물 35 종 중 4종의 구강 세균에 대하여 항균 스펙트럼이 넓고 항균 
Table 3 Minimum inhibitory concentrations of some plant extracts against oral bacteria growth

\begin{tabular}{lccccc}
\hline \hline \multirow{2}{*}{ Plant extracts } & \multicolumn{4}{c}{ Minimum inhibitory concentration $(\mu \mathrm{g} / \mathrm{mL})$} \\
\cline { 2 - 6 } & \multicolumn{4}{c}{ Gram $(+)$} & \multicolumn{2}{c}{ Gram $(-)$} \\
\cline { 2 - 6 } & S. mutans & L. casei & S. epidermidis & K. pneumoniae & E. coli \\
\hline Hibiscus sabdariffa & 5,000 & 20,000 & 625 & 1,250 & 1,250 \\
Schizandra chinensis & 20,000 & 20,000 & 156.3 & 1,250 & 2,500 \\
Citrus limon & 10,000 & - & 156.3 & 1,250 & 2,500 \\
Chaenomelis fructus & 20,000 & 5,000 & 5,000 & 5,000 & 10,000 \\
Salvia miltiorrhiza & - & $>30,000$ & 2,500 & $>30,000$ & - \\
Commiphora molmol Engl. & $>30,000$ & - & 10,000 & 20,000 & - \\
\hline
\end{tabular}

활성이 높은 히비스커스, 오미자, 레몬, 모과, 몰약, 단삼 추출 물을 1 차 선별하였으며, 최소저해농도(MIC) 측정을 통해 구강 세균에 대한 생장 저해능을 확인하였다.

\section{식용 식물추출물의 최소생육저해농도(MIC)}

Table 3과 같이 히비스커스, 오미자, 레몬 및 모과의 $70 \%$ ethanol 추출물은 충치균인 S. mutans에 대해 생장 저해능을 보 였는데 이 중에서 히비스커스 추출물이 가장 낮은 $\mathrm{MIC}$ 값 $(5$ $\mathrm{mg} / \mathrm{mL}$ )을 나타냈다. Lee와 $\operatorname{Kim}[29]$ 의 연구는 콩 추출물이 40 $\mathrm{mg} / \mathrm{mL}$ 이상의 농도에서 S. mutans의 생장을 억제하였다고 보 고한 바 있는데, 본 연구에서는 히비스커스 추출물의 S. mutans 에 대한 항균 활성이 콩 추출물보다 더 높은 것으로 나타났다. L. casei에 대한 식물추출물의 $\mathrm{MIC}$ 를 측정한 결과 Table 3에서 보는 바와 같이 paper disc법으로 1차 스크리닝 시 육안 관찰 에서 항균 활성을 보이지 않았던 히비스커스, 오미자, 레몬 및 모과에서 최소저해농도가 측정되었는데, 이는 $\mathrm{MIC}$ 측정 시 추 출물에 함유되어 있는 유기산에 의해 배지의 $\mathrm{pH}$ 가 낮아져 항 균 효과가 증가된 것으로 판단된다[30].

S. epidermidis에 대한 식물추출물의 $\mathrm{MIC}$ 를 측정한 결과, 모 든 추출물이 균의 증식을 억제하였고, 그 중 오미자와 레몬 추 출물이 가장 높은 저해능을 보였다 $(\mathrm{MIC}=156.3 \mu \mathrm{g} / \mathrm{mL}$ ). Lee 등 [31]은 S. epidermidis에 대한 레몬그라스 및 오렌지 에센셜 오 일의 최소저해농도를 각각 5 및 $10 \mathrm{mg} / \mathrm{mL}$ 로 보고한 바 있어, 본 연구에서 확인한 바, 히비스커스, 오미자, 레몬 및 단삼의 $70 \%$ ethanol 추출물 $(\mathrm{MIC}=0.156-2.5 \mathrm{mg} / \mathrm{mL})$ 이 $S$. epidermidis에 대해 레몬그라스나 오렌지 에센셜 오일보다 더 높은 항균 효과 를 가지는 것으로 판단된다.

K. pneumoniae에 대한 추출물의 $\mathrm{MIC}$ 를 측정한 결과, 히비스 커스, 오미자, 레몬, 모과 및 몰약 추출물은 항균 능력이 있었 으며, 그 중 히비스커스, 오미자 및 레몬이 모두 $1,250 \mu \mathrm{g} / \mathrm{mL}$ 의 가장 낮은 $\mathrm{MIC}$ 값을 나타냈다. $\mathrm{Goo}[32]$ 는 로즈마리 추출물 과 세이지 추출물이 고형분 농도 $6 \%$ 이상에서 $K$. pneumoniae 의 증식을 억제하였다고 보고한 바 있는데, 이와 비교해서도 히 비스커스, 오미자 및 레몬 추출물이 K. pneumoniae에 대한 항 균 활성이 더 높은 것으로 보인다.

대조군으로 사용된 보건지표균 E. coli에 대해서 히비스커스, 오미자 및 레몬 추출물이 생장 저해능을 보였는데 이 중에서 히비스커스가 가장 낮은 $\mathrm{MIC}$ 값 $(1,250 \mu \mathrm{g} / \mathrm{mL})$ 을 나타냈다. $\mathrm{Cho[33]}$ 의 연구에서 산수유 추출물이 $2 \mathrm{mg} / \mathrm{mL}$ 이상의 농도에 서 E. coli의 증식을 억제하는 최소저해농도 값을 나타냈다고
보고한 바 있으므로 히비스커스 추출물의 E. coli에 대한 항균 활성이 산수유 추출물보다 더 높은 것으로 판단된다.

이상의 항균 활성 분석 결과로부터 항균 활성의 범위가 넓고, 구강 관련 위해균과 E. coli에 대하여 우수한 항균 활성을 나타 내며 특히 충치균인 S. mutans에 대한 최소저해농도가 가장 낮 은 히비스커스 추출물을 구강 미생물에 대한 항균 소재로 발굴 하였다.

\section{히비스커스 추출물의 항균 활성의 안정성}

Table 3에서 보듯이 히비스커스 꽃으로부터 얻어진 $70 \%$ 에탄 올 추출물이 구강 세균의 생장을 효과적으로 저해하는 것으로 나타나 히비스커스 추출물을 대상으로 $\mathrm{pH}$ 와 온도에 대한 안정 성을 확인하였다.

히비스커스 꽃 추출물에 들어있는 항균 활성 물질을 구강 위 생용 생리활성 소재로 활용하기 위해서는 $\mathrm{pH}$ 와 열에 대한 안 정성이 높아야 한다. 히비스커스 추출물의 $\mathrm{pH}$ 를 각각 $3,5,7$ 및 9 로 조절하여 $25^{\circ} \mathrm{C}$ 에서 3 시간 동안 방치한 후 원래 $\mathrm{pH}$ 로 다시 조절하여 최소저해농도를 측정한 결과는 다음과 같다.

S. mutans의 경우 $\mathrm{pH}$ 3에서는 히비스커스 추출물의 $\mathrm{MIC}$ 값 이 $5,000 \mu \mathrm{g} / \mathrm{mL}$ 이었으나 $\mathrm{pH} 5$ 이상일 경우 $\mathrm{MIC}$ 값이 20,000 $\mu \mathrm{g} / \mathrm{mL}$ 으로 나타나 항균 활성이 감소하는 것으로 나타났다. $S$. epidermidis에 대한 $\mathrm{MIC}$ 값은 $\mathrm{pH}$ 3-7 범위에서 각각 $625 \mu \mathrm{g} /$ $\mathrm{mL}$ 로 안정하게 유지되었지만, $\mathrm{pH}$ 9에서는 $\mathrm{MIC}$ 값이 $5,000 \mu \mathrm{g} /$ $\mathrm{mL}$ 로 나타나 항균 활성이 알칼리 조건에서 낮아지는 것으로 나 타났다.

E. coli에 대한 $\mathrm{MIC}$ 값은 $\mathrm{pH} 3-7$ 범위에서 $1,250 \mu \mathrm{g} / \mathrm{mL}$ 로 안정하게 유지되었지만, $\mathrm{pH}$ 9에서는 $\mathrm{MIC}$ 값이 $2,500 \mu \mathrm{g} / \mathrm{mL}$ 로 나타나 항균 활성이 감소하였다.

L. casei와 K. pneumoniae에 대한 $\mathrm{MIC}$ 값은 각각 10,000 와 $1,250 \mu \mathrm{g} / \mathrm{mL}$ 로 나타나 $\mathrm{pH}$ 3-9의 넓은 $\mathrm{pH}$ 범위에서도 항균 활 성이 안정하게 유지됨을 확인하였다.

이상으로 히비스커스 추출물의 항균 활성은 산성 조건에서 가장 안정하게 유지됨을 알 수 있었으며, 이는 히비스커스가 특 유의 신맛과 유기산을 함유하고 있어서 재료 본래의 $\mathrm{pH}$ 가 낮 아 산성에 더 안정한 것으로 판단된다. 구강청결제, 치약 등의 구강 청결 제품은 다양한 $\mathrm{pH}$ 범위의 제품이 존재하며, 히비스 커스 추출물이 그 중 약산성 제품의 항균소재로 적용될 경우 안정한 항균 활성을 유지할 수 있을 것으로 사료된다.

또한 히비스커스 추출물을 각각 $4,25,50$ 및 $75^{\circ} \mathrm{C}$ 에서 30 분간 방치한 후 최소저해농도를 측정한 결과, 모든 균이 $4-75^{\circ} \mathrm{C}$ 
Table 4 polyphenol, and flavonoid contents of $70 \%$ ethanol extract from Hibiscus sabdariffa flowers

\begin{tabular}{cc}
\hline \hline Polyphenol content ${ }^{1}(\mathrm{mg} \mathrm{CAE} / \mathrm{g})$ & Flavonoid content $^{2)}(\mathrm{mg} \mathrm{NE} / \mathrm{g})$ \\
\hline $130.5 \pm 32.6^{3)}$ & $25.7 \pm 2.8^{3)}$
\end{tabular}

${ }^{1}$ Polyphenol content was expressed as chlorogenic acid equivalents (CAE)

${ }^{2)}$ Flavonoid content was expressed as naringin equivalents (NE)

${ }^{3)}$ Results represent mean and SD of triplicate measurements

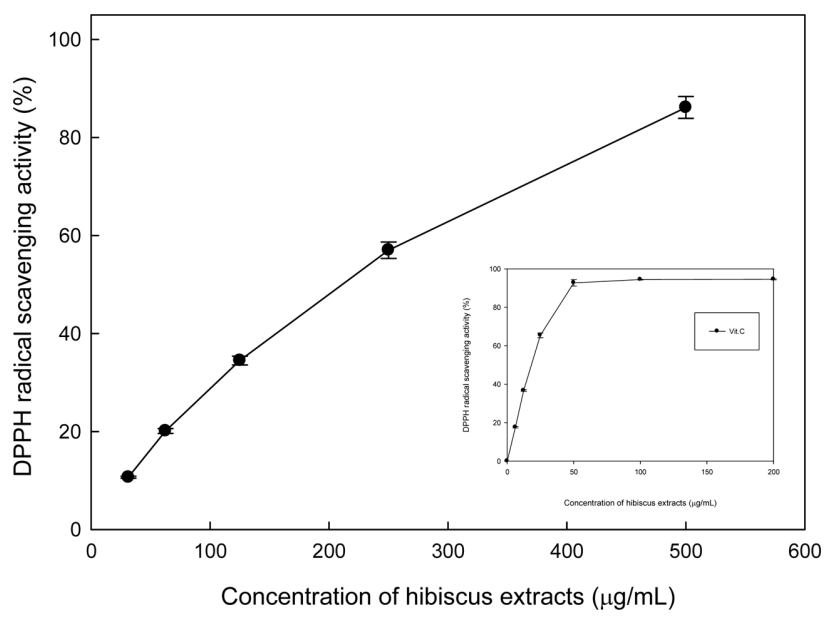

Fig. 1 DPPH free radical scavenging activity of Hibiscus sabdariffa extract. Results were mean and SD of triplicate measurements

까지의 넓은 온도 범위에서 일정한 $\mathrm{MIC}$ 값을 나타냈다. 그 값 은 S. mutans, L. casei, S. epidermidis, K. pneumoniae 및 E. coli에서 각각 $5,000,10,000,625,1,250$ 및 $1,250 \mu \mathrm{g} / \mathrm{mL}$ 으 로 나타났으며, 이에 따라 히비스커스 추출물은 열에 안정한 것 으로 사료된다.

이상으로 히비스커스 꽃 추출물의 항균 물질은 열 안정성이 우수하고 산성 조건에서 안정한 것으로 확인되어 향후 구강용 품 및 연관 제품에 적용할 경우 활용성이 높을 것으로 사료된다.

\section{히비스커스 추출물의 폴리페놀 함량 및 항산화 활성}

폴리페놀은 화학 구조에 따라 플라보노이드계와 비플라보노이 드계로 구분되는 생리활성 물질로 항산화, 항염증 및 항돌연변 이 활성[34]뿐만 아니라, 특히 강력한 항균 효과[35]를 갖는 것 으로 알려져 있다. 히비스커스 추출물의 총 폴리페놀 함량은 $130.5 \mathrm{mg} / \mathrm{g}$ 이었고, 총 플라보노이드 함량은 $25.7 \mathrm{mg} / \mathrm{g}$ 으로 나타 났다(Table 4). 이 결과는 $\mathrm{Kim}$ 과 $\operatorname{Jin}[36]$ 의 연구에서 히비스커 스의 총 폴리페놀 함량이 $131.8 \mathrm{mg} / \mathrm{g}$ 이라는 결과와 거의 유사 하였고, 플라보노이드 함량의 경우에는 Lee 등[37]이 보고한 흰 무궁화 꽃의 플라보노이드 함량 $(47.74 \mathrm{mg} / \mathrm{g})$ 에 비해 다소 낮게 나타났다. 실제로 카테킨과 플라보노이드계 등의 폴리페놀 화합 물이 상당량 들어있는 것으로 알려진 차잎의 폴리페놀 함량(건 조 중량 대비 10-25\%)[38]과 비교해서도 히비스커스 추출물의 폴리페놀 함량은 비교적 높은 수준으로 볼 수 있다.

히비스커스 꽃 추출물의 DPPH 유리라디칼 소거활성과 Ferrous 이온에 대한 환원력을 확인하였다. 히비스커스 추출물

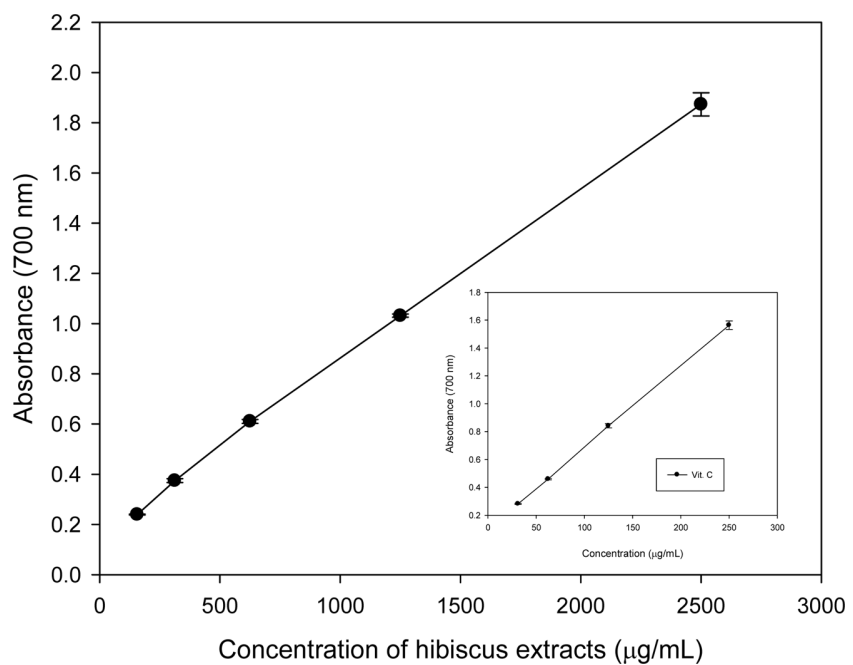

Fig. 2 Ferric reducing anti-oxidant power of Hibiscus sabdariffa extract. Results were mean and SD of triplicate measurements

은 농도 증가에 비례하여 $\mathrm{DPPH}$ 라디칼을 효과적으로 소거하 였다(Fig. 1). 히비스커스 추출물은 $500 \mu \mathrm{g} / \mathrm{mL}$ 의 농도에서 $86.1 \%$ 의 유리라디칼을 소거하였고, $\mathrm{DPPH}$ 유리라디칼을 $50 \%$ 소거하는 농도인 $\mathrm{EC}_{50}$ 값은 $246.7 \mu \mathrm{g} / \mathrm{mL}$ 으로 나타나 히비스커스 추출물은 유리라디칼 소거 항산화 능력이 우수함을 알 수 있었 다. 이와 같은 결과는 Shin과 $\mathrm{Ha}[39]$ 의 연구에서 알려진 무궁 화 추출물의 DPPH 유리라디칼 소거활성과 유사하였다. 히비스 커스 추출물의 환원력도 농도에 비례하여 증가하였고(Fig. 2), 반응액의 흡광도가 0.5 에 달하는 농도인 $\mathrm{RC}_{0.5}$ 값은 $490.0 \mu \mathrm{g} / \mathrm{mL}$ 으로 나타났다. 이는 백연수잎 추출물의 $\mathrm{RC}_{0.5}$ 값인 $250.0 \mu \mathrm{g} / \mathrm{mL}$ [40] 보다는 높았으나 복분자 추출물의 $\mathrm{RC}_{0.5}$ 값인 $840.0 \mu \mathrm{g} / \mathrm{mL}$ [41] 보다는 크게 낮아 환원력이 우수함을 알 수 있었다.

이상의 결과로부터 35종의 식용 식물 중 히비스커스, 오미자, 레몬, 모과, 몰약, 및 단삼 추출물이 구강 세균에 대한 항균 소 재로 선별되었고, 그 중 항균 스펙트럼 및 항균 활성이 가장 우 수한 히비스커스 추출물을 구강 세균용 항균 및 생리활성 소재 로 최종 선발하였다. 히비스커스 추출물은 상당량의 폴리페놀과 플라보노이드 화합물을 함유하고 있었고, 높은 항산화 활성을 보여주었다. 따라서 히비스커스 추출물은 구강용 항균 및 항산 화 활성을 가진 기능성 원료로 활용가능성이 높을 것으로 사료 되며, 향후 히비스커스 추출물의 추출 조건 최적화 및 구강용 품에 적용한 연구에 대해 검토할 필요가 있다.

\section{초 록}

식용 식물 35 종의 생리활성 부위를 대상으로 $70 \%$ 에탄올 추출 물의 구강 세균(Streptococcus mutans, Lactobacillus casei, Staphylococcus epidermidis, Klebsiella pneumoniae)에 대한 항 균 활성을 확인하였다. 35 종의 식물추출물 중 항균 스펙트럼이 가장 넓고 최소저해농도가 낮은 히비스커스 꽃 추출물을 구강 세균에 대한 항균 소재로 최종 선발하였다. 히비스커스 추출물 의 항균 활성은 산성 조건에서 안정하였고, 열 안정성이 우수 
하였다. 히비스커스 추출물의 총 폴리페놀 및 총 플라보노이드 함량은 130.5 및 $25.7 \mathrm{mg} / \mathrm{g}$ 으로 나타났고, 유리라디칼 소거활성 과 환원력의 항산화 활성이 우수하였다.

Keywords 구강 세균 - 식용 식물추출물 - 최소저해농도 - 항균 활성 $\cdot$ Hibiscus sabdariffa

감사의 글 본 논문은 제 1 저자의 석사학위논문 “구강 세균에 대한 히비스 커스의 항균 효과 및 생리활성 평가에 관한 연구”를 바탕으로 작성되었습니다.

\section{References}

1. Heo NS (2012) Study on antimicrobial activities against oral pathogens and deodorizing effects of Korean endemic plants. Dissertation, Changwon National University

2. Islam B, Khan SN, Khan AU (2007) Dental caries: From infection to prevention. Med Sci Monit 13: 196-203

3. Lin YJ, Chou C, Hsu CS (2017) Effects of Lactobacillus casei Shirota intake on caries risk in children. J Dental Sci 12: 179-184

4. Choi JL, Jung MA, Jung SH (2006) Antimicrobial effect of mulberry leaves extracts against oral microorganism. J Den Hyg Sci 6: 251-254

5. Gaffar MC, Fischer TJ, Gaffar A (1979) Instrumental evaluation of odor produced by specific oral microorganisms. J Soc Cosmet Chem 30: 241247

6. Moon JS, Ahn JE, Han AR, Heo JS, Eom HJ, Shin CS, Choi HS, Han NS (2011) Anticariogenic activities of Lactobacillus sakei K-7 isolated from Kimchi. KSBB Journal 26: 513-516

7. Park YM (2006) Anticariogenic and antioxidant activity of processed salt with medicinal herb. Dissertation, Mokpo National University

8. Filoche SK, Soma K, Sissons CH (2005) Antimicrobial effects of essential oils in combination with chlorhexidine digluconate. Oral Microbiol Immunol 20: 221-225

9. Lee KH, Choi CH, Hong SJ (2012) Relationship of the use of some fluoride containing dentifrice on the Korean market to children's fluoride intake in different age groups. J Korean Soc Dent Hyg 12: 881-896

10. Yoo YK, Ro JS, Kim JS, Chang KW (1996) The antibacterial effects of some propolis constituents against $S$. mutans, Lactobacilli and Actinomyces. J Acad Dent Health 20: 65-74

11. Park YM, Kim SJ, Jo KH, Yang EJ, Jung ST (2006) Anticariogenic and antioxidant activities from medicinal herbs. J Korean Soc Food Sci Nutr 35: 284-293

12. Kim SY, Shin SC, Seo HS (2002) Comparative study on remineralizing effect of sorbitol, xylitol and erythritol sweetened chewing gums. J Acad Dent Health 26: 593-607

13. Cowan MM (1999) Plant products as antimicrobial agents. J Clin Microbiol Rev 12: 564-582

14. Park IB (2006) Anticariogenic activities of Chrysanthemum indicum L. and its processed salt. Dissertation, Mokpo National University

15. Jang GH (2000) Anticariogenic effects of Coptis chinensis Franch extract. Dissertation, Chonbuk National University

16. Choi H, Koh YJ, Choi IW, Kim YS, Park YK (2007) Anticariogenic activity and glucosyltransferase inhibitory effects of extracts from pine needle and twig. Korean J Food Sci Technol 39: 336-341

17. Heo NS, Choi HJ, Hwang SM, Choi YW, Lee YG, Joo WH (2013) Antimicrobial and anti-oral malodor efficacy of Schizandra chinensis extracts against oral pathogens. J Life Sci 23: 443-447

18. Lee HE (2012) Growth inhibition of Streptococcus sp. causes oral disease by methanol extract of lotus (Nelumbo nucifera) leaf. Dissertation, Dongeui University
19. Cho IS, Lee JS (2015) Combination dyeing of silk fabrics with hibiscus flowers and persimmon juice extract. J Fashion Text Res 17: 476-485

20. Cho IS (2015) Natural dyeing of fabrics with Hibiscus syriacus L. and Hibiscus subdariffa L. extract. Dissertation, Gyeongsang National University

21. Choi SH (2008) Volatile aroma components of hibiscus herb tea. J Kor Tea Soc 14: 195-204

22. Kang PS, Seok JH, Kim YH, Eun JS, Oh SH (2007) Antimicrobial and antioxidative effects of roselle (Hibiscus sabdariffa L.) flower extract and its fractions on skin microorganisms and oxidation. Korean J Food Sci Technol 16: 409-414

23. Higasi GS (2000) Appraisement of antioxidative activity from vegetables. Jpn J Food Ind 57: 56-64

24. Lee YS, Joo EY, Kim NW (2006) Polyphenol contents and physiological activity of the Lespedeza bicolor extracts. J Food Preserv 13: 616-622

25. Kim EJ, Choi JY, Yu MR, Kim MY, Lee SH, Lee BH (2012) Total polyphenols, total flavonoid contents, and antioxidant activity of Korean natural and medicinal plants. Korean J Food Sci Technol 44: 337-342

26. Heo JC, Park JY, An SM, Lee JM, Tun CY, Shin HH, Kwon TK, Lee SH (2006) Anti-oxidant and anti-tumor activities of crude extracts by Gastrodia elata Blume. Korean J Food Sci Technol 13: 83-87

27. Hazra B, Biswas S, Mandal N (2008) Antioxidant and free radical scavenging activity of Spondias pinnata. J BMC Complement Altern Med 8: 63

28. Jeong HJ, Lee YA, Ji WD (2002) Effect of the extract of Schisandra chinensis Baill on bacteria isolated from oral cavity. J Dental Hygiene Sci 2: 85-88

29. Lee SL, Kim JG (2006) Anti-microbial activity of soybean extract against oral microbes. J Env Health 32: 192-197

30. Park UY, Chang DS, Cho HR (1992) Screening of antimicrobial activity for medicinal herb extracts. J Korean Soc Food Nutr 21: 91-96

31. Lee SY, Kim JG, Baek BJ, Yang YM, Lee GY, Lee YH, Kim MA (2009) Antimicrobial effect of essential oils on oral bacteria. J Korean Acad Pediatr Dent 36: 1-11

32. Goo SA (2004) Dyeability and antibacterial activity of the fabrics dyed with herbs extract. Dissertation, Changwon National University

33. Cho DB (2001) A Study on the constituents and antimicrobial substance during the growth stage of Lentinus edodes Sing. Dissertation, Sunchon Nation University

34. Thitimuta S, Pithayanukul P, Nithitanakool S, Bavovada R, Leanpolchareanchai J, Saparpakorn P (2017) Camellia sinensis L. extract and its potential beneficial effects in antioxidant, anti-inflammatory, antihepatotoxic, and anti-tyrosinase activities. Molecules 22: 401

35. Xie Y, Chen J, Xiao A, Liu L (2017) Antibacterial activity of polyphenols: structure-activity relationship and influence of hyperglycemic condition. Molecules 22: 1913

36. Kim MJ, Jin SY (2017) Antioxidant activity of quality characteristics of Hibisus syriacus cultivars powders. J Kor Soc Food Cult 32: 295-302

37. Lee HJ, Lee SW, Park CG, Ahn YS, Kim JS, Bang MS, Oh CH, Kim CT (2015) Effects of white Habiscus syriacus L. flower extracts on antioxidant activity and bone resorption inhibition. Kor J Medicinal Crop Sci 23: 190-197

38. Choi OJ, Choi KH (2003) The physicochemical properties of Korean wild teas (green tea, semi-fermented tea, and black tea) according to degree of fermentation. J Korean Soc Food Sci Nutr 32: 356-362

39. Shin YB, Ha BJ (2016) Effects of Hibiscus syriacus extracts on antioxidant activities and blood circulation improvement. J Life Sci 26: 1415-1421

40. Kim DC, In MJ (2017) Antioxidative ability of ethanol extract from the leaves of Leucaena leucocephala (Lam.) de Wit. J Appl Biol Chem 60:185-190

41. Jun HI, Kim YA, Kim YS (2014) Antioxidant activities of Rubus coreanus Miquel and Morus alba L. fruits. Korean Soc Food Sci Nutr 43: $381-388$ 